\title{
PENGARUH TUNJANGAN SERTIFIKASI TERHADAP KINERJA GURU SMP NEGERI SEKECAMATAN MEUREUBO KABUPATEN ACEH BARAT
}

\author{
Damrus \\ Fakultas Ekonomi, Universitas Teuku Umar \\ email: $\underline{\text { damrus@utu.ac.id }}$
}

\begin{abstract}
Teachers' performance determines the quality of educational system. Education will be qualified when teachers are referred to the organized vision, mission, purpose, and goal in order to respond to various changes by generating all potential resources in educational institution. Teachers' work satisfaction is one of the important aspects which have to be heeded by management in order to increase teachers' quality of performance. When work satisfaction is fulfilled, teachers will tend to have high morale in doing their job. The research used descriptive explanatory quantitative method which was aimed to measure the correlation between two or more variables. The data were gathered by conducting interviews, questionnaires, and documentary study. The population was 39 teachers as the government employees at all public junior high schools in Meureubo Subdistrict who had received certification allowance, and all of them were used as the samples, taken by using census sampling technique. The gathered data were analyzed by using interval scale, and multiple regression. The result of the research showed that certification allowance had positive and significant influence on teachers' performance.
\end{abstract}

Keywords: Certification Allowance, Teachers' Performance

\section{PENDAHULUAN}

Latar Belakang Masalah

Kinerja guru merupakan penentu tinggi rendahnya mutu pendidikan. Pendidikan dinyatakan bermutu bila guru mengacu pada visi, misi, tujuan, sasaran dan target yang disusun untuk menjawab berbagai perubahan dengan menggerakkan seluruh potensi sumberdaya yang ada dalam lembaga pendidikan.

Tingginya kinerja guru dapat dibuktikan dengan kewenangan dan tanggungjawab kerja terhadap: perencanaan pembelajaran, pelaksanaan pembelajaran, evaluasi program sekolah, pengelolaan kurikulum, pengelolaan peralatan sekolah, pengelolaan siswa dan hubungan antar guru. Wibowo (2012) seseorang pasti ingin mendapatkan pekerjaan karena dengan bekerja ia mengharapkan mendapat imbalan untuk menghidupi dirinya dan keluarganya. Namun, seringkali terjadi bahwa mendapatkan imbalan saja dirasakan belum cukup. Mereka menginginkan mendapatkan kepuasan dari pekerjaannya. 
Namun cita-cita mewujudkan pendidikan bermutu tersebut tidaklah mudah, pendidikan dihadapkan pada berbagai permasalahan. Keterpurukan mutu pendidikan di Indonesia seperti laporan UNESCO dalam Education For All Global Monitoring Report (EFA-GMR), Indeks Pembangunan Pendidikan Untuk Semua atau The Education for All Development Index (EDI) Indonesia tahun 2014 berada pada peringkat 57 dari 115 .

Selain itu, Badan Program Pembangunan PBB (UNDP) kembali merilis Indeks Pembangunan Manusia (IPM) terbaru untuk tahun 2013. Dalam laporan mereka, Indonesia berada di peringkat 108 dari 187 negara yang dinilai. Bila dibandingkan dengan Negara negara ASEAN yang dilibatkan dalam penelitian tersebut, Indonesia berada pada peringkat ke-7 dari sembilan negara ASEAN. Salah satu unsur utama dalam penentuan komposit Indeks Pengembangan Manusia ialah tingkat pengetahuan bangsa atau pendidikan bangsa. Peringkat Indonesia yang rendah dalam kualitas sumber daya manusia ini adalah gambaran mutu pendidikan Indonesia yang rendah.

Salah satu penyebab rendahnya mutu pendidikan di Indonesia adalah komponen mutu guru. Mengingat bahwa salah satu aspek dari proses pendidikan adalah kegiatan pembelajaran yang tidak bisa dilepaskan dari peran dan fungsi guru, sehingga dalam upaya membelajarkan siswa guru dituntut memiliki multi peran agar mampu menciptakan kondisi belajar mengajar yang efektif. Rendahnya profesionalitas guru di Indonesia dapat dilihat dari kelayakan guru dalam mengajar.

Indikator lainnya mengenai kondisi komptenesi guru yang rendah dapat dilihat dari hasil Uji Kompetensi Guru (Kemdikbud 2015) untuk Aceh menunjukkan rata-rata secara keseluruhan yang diperoleh hanya 45,27, yang masih jauh dari nilai yang dikehendaki pemerintah yaitu 70 poin sehingga dapat disimpulkan profesionalisme guru di Provinsi Aceh dari segi nilai pedagogik dan nilai professional yang dilihat dari hasil UKG bisa dikatakan masih rendah dan masih banyak mengalami kekurangan.

Kondisi ini membenarkan kenyataan bahwa selama ini peranan dan fungsi guru yang sangat penting tersebut belum sepenuhnya dapat dijalankan oleh para guru. Sebagian besar guru tidak menekuni profesinya secara utuh. Arti pentingnya kinerja guru sangat erat kaitannya dengan upaya peningkatan mutu pendidikan. Karenanya, upaya peningkatan kinerja guru merupakan salah satu solusi guna mengatasi permasalahan rendahnya kualitas pendidikan. Sesuai dengan pendapat Liwes (1999: 54) yang menyatakan bahwa "Guru yang professional merupakan salah satu jaminan terlaksananya kegiatan belajar-mengajar yang lebih efektif, dan dengan kualitas guru maka proses belajar-mengajar diharapkan akan berhasil secara optimal". Dari pandangan tersebut, jelaslah bahwa keberadaan guru dalam proses belajar mengajar memiliki peranan penting dan dominan terutama dalam proses transformasi pengetahuan kepada siswa.

Adapun unsur-unsur yang turut mempengaruhi kinerja guru menurut Silalahi (1995) antara lain: kondisi fisik sekolah, dinamika kurikulum pendidikan, ketersediaan sarana dan prasarana pendidikan, imbalan atau gaji guru, tambahan penghasilan atau insentif guru, pendidikan dan pelatihan guru, kondisi sosial budaya masyarakat, tingkat pendidikan guru, kepemimpinan kepala sekolah, perkembangan ilmu pengetahuan dan teknologi.

Berikut data guru Guru Negeri Sipil (PNS) di Sekolah Menegah Pertama Negeri (SMP N) sekecamatan Meureubo: 


\section{Tabel 1}

Data Guru SMP Negeri se Kecamatan Meureubo Kabupaten Aceh Barat

\begin{tabular}{|c|c|c|c|c|c|}
\hline \multirow[t]{2}{*}{ No } & \multirow[t]{2}{*}{ Nama Sekolah } & \multicolumn{2}{|c|}{$\begin{array}{c}\text { Jumlah guru } \\
\text { yang telah } \\
\text { menerima } \\
\text { tunjangan } \\
\text { sertifikasi }\end{array}$} & \multicolumn{2}{|c|}{$\begin{array}{c}\text { Jumlah guru } \\
\text { yang belum } \\
\text { merima } \\
\text { tunjangan } \\
\text { sertifikasi }\end{array}$} \\
\hline & & orang & $\%$ & orang & $\%$ \\
\hline 1 & $\begin{array}{l}\text { SMP Negeri } 1 \\
\text { Meureubo }\end{array}$ & 4 & $57 \%$ & 3 & $43 \%$ \\
\hline 2 & $\begin{array}{c}\text { SMP Negeri } 2 \\
\text { Meureubo }\end{array}$ & 17 & $71 \%$ & 7 & $29 \%$ \\
\hline 3 & $\begin{array}{c}\text { SMP Negeri } 3 \\
\text { Meureubo }\end{array}$ & 4 & $44 \%$ & 5 & $56 \%$ \\
\hline 4 & $\begin{array}{l}\text { SMP Negeri } 4 \\
\text { Meureubo }\end{array}$ & 4 & $57 \%$ & 3 & $43 \%$ \\
\hline 5 & $\begin{array}{c}\text { SMP Negeri } 5 \\
\text { Meureubo }\end{array}$ & 4 & $36 \%$ & 7 & $64 \%$ \\
\hline \multirow[t]{2}{*}{6} & $\begin{array}{l}\text { SMP Negeri } 6 \\
\text { Meureubo }\end{array}$ & 6 & $55 \%$ & 5 & $45 \%$ \\
\hline & Total & 39 & $57 \%$ & 30 & $43 \%$ \\
\hline
\end{tabular}

\section{Sumber: Dinas Pendidikan Kabupaten Aceh Barat, Tahun 2015.}

Tunjangan sertifikasi merupakan suatu usaha pemerintah dalam meningkatkan kesejahteraan guru, dimana salah satu harapan pemerintah agar dengan adanya tunjangan sertifikasi mampu memenuhi kebutuhan hidup guru dan keluarganya. Akan tetapi jika dilihat dari realita fenomena yang ada, hampir 90\% guru mengagunkan SK PNS mereka dibank. Hal ini menunjukkan bahwa tunjangan sertifikasi belum mampu memenuhi kebutuhan hidup guru.

Kinerja guru sangat penting untuk diperhatikan dan dievaluasi karena guru berkualitas akan menghasilkan siswa/i yang berkualitas, sumber daya manusia yang bagus dan eksistensi keberlangsungan suatu Negara. 
Tabel 2

Data Fenomena Realita Kinerja Guru SMP se Kecamatan Meureubo Kabupaten Aceh Barat tahun 2015

\begin{tabular}{|c|c|c|c|c|}
\hline No & Realita Kinerja Guru & $\begin{array}{c}\text { Rata-rata } \\
\text { hasil } \\
\text { penilaian } \\
\text { guru sudah } \\
\text { sertifikasi }\end{array}$ & $\begin{array}{c}\text { Rata-rata } \\
\text { hasil } \\
\text { penilaian } \\
\text { guru belum } \\
\text { sertifikasi }\end{array}$ & Selisih \\
\hline 1 & Menguasai karakteristik peserta didik & 3.31 & 3.00 & 0.31 \\
\hline 2 & $\begin{array}{l}\text { Menguasai teori belajar dan prinsip- } \\
\text { prinsip pembelajaran yang mendidik }\end{array}$ & 3.25 & 3.00 & 0.25 \\
\hline 3 & Pengembangan kurikulum & 3.13 & 3.00 & 0.13 \\
\hline 4 & Kegiatan pembelajaran yang mendidik & 3.56 & 4.00 & -0.44 \\
\hline 5 & Pengembangan potensi peserta didik & 3.00 & 3.00 & 0.00 \\
\hline 6 & Komunikasi dengan peserta didik & 3.75 & 4.00 & -0.25 \\
\hline 7 & Penilaian dan evaluasi & 3.06 & 3.00 & 0.06 \\
\hline 8 & $\begin{array}{l}\text { Bertindak sesuai dengan norma } \\
\text { agama, hukum, sosial dan kebudayaan } \\
\text { nasional }\end{array}$ & 3.75 & 3.00 & 0.75 \\
\hline 9 & $\begin{array}{l}\text { Menunjukkan pribadi yang dewasa } \\
\text { dan teladan }\end{array}$ & 3.38 & 3.00 & 0.38 \\
\hline 10 & $\begin{array}{l}\text { Etos kerja, tanggung jawab yang } \\
\text { tinggi, rasa bangga menjadi guru }\end{array}$ & 3.56 & 3.00 & 0.56 \\
\hline 11 & $\begin{array}{l}\text { Bersikap inklusif, bertindak obyektif, } \\
\text { serta tidak diskriminatif }\end{array}$ & 3.63 & 3.00 & 0.63 \\
\hline 12 & $\begin{array}{l}\text { Komunikasi dengan sesama guru, } \\
\text { tenaga kependidikan, orang tua, } \\
\text { peserta didik, dan masyarakat }\end{array}$ & 3.50 & 4.00 & -0.50 \\
\hline 13 & $\begin{array}{l}\text { Penguasaan materi, struktur, konsep } \\
\text { dan pola pikir keilmuan yang } \\
\text { mendukung mata pelajaran yang } \\
\text { diampu }\end{array}$ & 3.00 & 3.00 & 0.00 \\
\hline \multirow[t]{2}{*}{14} & $\begin{array}{l}\text { Mengembangkan keprofesionalan } \\
\text { melalui tindakan yang reflektif }\end{array}$ & 3.50 & 3.00 & 0.50 \\
\hline & Rata-rata & 3,38 & 3,21 & 0,17 \\
\hline
\end{tabular}

\section{Sumber : Rekap Hasil Penilaian Kinerja 17 orang Guru}

Dari Tabel 2 diatas menunjukkan hasil rekap penilaian kinerja guru dari enam SMP Negeri di Kecamatan Meureubo Kabupaten Aceh Barat, peneliti membandingkan kinerja guru yang telah menerima tunjangan sertifikasi dengan yang belum menerima tunjangan sertifikasi. Adapun rata-rata kinerja guru yang telah menerima tunjangan sertifikasi adalah sebesar 3,38, sedangkan rata-rata kinerja guru yang belum menerima tunjangan sertifikasi yaitu sebesar 3,21, ini menunjukkan bahwa rata-rata kinerja guru yang telah menerima tunjangan sertifikasi lebih tinggi 0,17 dibandingkan dengan kinerja guru yang belum menerima tunjangan sertifikasi. Akan tetapi dalam hal kegiatan pembelajaran yang mendidik, komunikasi dengan peserta didik, komunikasi dengan sesama guru, tenaga kependidikan, orang tua, peserta didik, dan masyarakat hasil rata-ratanya menunjukkan guru yang belum menerima 
tunjangan sertifikasi nilai rata-ratanya lebih tinggi dibandingkan dengan guru yang telah menerima tunjangan sertifikasi.

Atas dasar realita fenomena dan uraian diatas maka akan dilakukan penelitian dengan judul Pengaruh Tunjangan Sertifikasi terhadap kinerja guru SMP Negeri sekecamatan Meureubo Kabupaten Aceh Barat.

\section{Tujuan Penelitian dan Manfaat Penelitian}

\section{Tujuan dari penelitian ini adalah :}

Untuk mengetahui dan manganalisis pengaruh tunjangan sertifikasi terhadap kinerja guru SMP Negeri se Kecamatan Meureubo Kabupaten Aceh Barat.

\section{Manfaat Penelitian}

1. Bagi Instansi

Sebagai masukan kepada SMP N se Kecamatan Meureubo Kabupaten Aceh Barat dalam usaha meningkatkan kinerja guru.

2. Bagi Sekolah Pasca Sarjana Ilmu Manajemen

Untuk menambah pengetahuan Bagi Kalangan Akademis sebagai referensi bagi penelitian selanjutnya dan memberikan sumbangan terhadap pengembangan ilmu pengetahuan

3. Bagi peneliti

Sebagai usaha untuk melatih, meningkatkan, mengembangkan kemampuan berpikir peneliti melalui penulisan karya ilmiah

4. Bagi Peneliti Selanjutnya

Sebagai bahan masukan dan pertimbangan dalam menambah pengetahuan bagi peneliti selanjutnya tentang Pemberian Tunjangan Sertifikasi, Pendidikan dan Pelatihan serta Kepemimpinan Kepala Sekolah terhadap Kinerja Guru pada SMP Negeri se Kecamatan Meureubo Kabupaten Aceh Barat.

\section{TINJAUAN PUSTAKA}

\section{Kinerja Guru}

Moeheriono (2009), kinerja merupakan deskripsi dalam hal tingkat pencapaian pelaksanaan dari suatu program kegiatan atau kebijakan dalam mewujudkan sasaran, tujuan, visi dan misi organisasi yang dicantumkan melalui perencanaan strategis organisasi. Dalam menjalankan fungsinya, kinerja tidak berdiri sendiri akan tetapi selalu berhubungan dengan kepuasan kerja karyawan dan tingkat besaran imbalan yang diberikan, serta dipengaruhi oleh keterampilan, kemampuan, dan sifat-sifat individu.

Menurut Ilyas (2001) kinerja adalah penampilan hasil karya personel baik kualitas maupun kuantitas dalam suatu organisasi. Kinerja dapat merupakan penampilan individu maupun kelompok kerja. Penampilan hasil karya tidak terbatas kepada personel yang memangku jabatan fungsional maupun struktural tetapi juga kepada keseluruhan jajaran personel dalam organisasi.

Sedangkan menurut Mangkunegara (2009) pengertian kinerja adalah hasil kerja secara kualitas dan kuantitas yang dicapai oleh seorang guru dalam melaksanakan tugasnya sesuai dengan tanggung jawab yang diberikan kepadanya.

Dalam Undang-Undang Republik Indonesia Nomor 14 Tahun 2005 tentang Guru dan Dosen, pasal 1, ayat (1) menjelaskan bahwa: "Guru adalah pendidik professional dengan tugas utamanya 
mendidik, mengajar, membimbing, mengarahkan, melatih, menilai dan mengevaluasi peserta didik pada pendidikan anak usia dini, jalur pendidikan formal, pendidikan dasar, dan pendidikan menengah". Sehingga, guru yang semakin bermutu semakin besar sumbangannya bagi perkembangan diri siswanya dan perkembangan masyarakatnya. Tugas utama guru tersebut merupakan indikator yang akan dijadikan untuk mengukur kinerja guru dalam melaksanakan tugasnya.

\section{Faktor-faktor yang Mempengaruhi Kinerja Guru}

Menurut Mulyasa (2007) terdapat 10 faktor yang mempengaruhi kinerja guru yang dapat diungkap antara lain: (a) dorongan untuk bekerja (b) tanggung jawab terhadap tugas (c) minat terhadap tugas (d) penghargaan atas tugas (e) peluang untuk berkembang (f) perhatian dari kepala sekolah (g) hubungan Interpersonal sesama guru (h) adanya pelatihan (i) kelompok diskusi terbimbing (j) Layanan perpustakaan.

\section{Tunjangan Sertifikasi Guru}

Program sertifikasi guru diharapkan pemerintah dapat mengatasi permasalahan kualitas pendidikan. Melalui program sertifikasi diharapkan kinerja guru akanmeningkat. Tunjangan profesi pendidik (TPP) merupakan bentuk tunjangan yangdiberikan kepada guru agar dapat meningkatkan kinerja profesinya.

Hasibuan (2005) menyatakan tunjangan adalah semua pendapatan yang berbentuk uang, barang langsung atau tidak langsung yang diterima oleh guru sebagai imbalan atas jasa yang diberikan atas suatu organisasi atau organisasi. Mangkunegara (2007) menyatakan bahwa "Pemberian tunjangan adalah suatu penghargaan dalam bentuk uang yang diberikan oleh pihak pimpinan organisasi kepada pegawai agar mereka bekerja dengan motivasi tinggi dan berprestasi dalam mencapai tujuan-tujuan organisasi atau dengan kata lain pemberian tunjangan merupakan pemberian uang di luar gaji yang dilakukan oleh pihak pimpinan organisasi sebagai pengakuan terhadap prestasi kerja dan kontribusi pegawai kepada organisasi”.

Nawawi(2008) menyatakan bahwa tunjangan bagi organisasi atau perusahaan berarti penghargaan pada para pekerja yang telah memberikan kontribusi dalam mewujudkan tujuannya melalui bekerja. Dengan kata lain tunjangan itu adalah hal-hal atau usaha yang harus diperhatikan dan dibangun untuk menggairahkan guru agar rajin bekerja dan dapat mencapai hasil yang lebih baik sehingga tercipta efektifitas kerja guru. Pengertian efektifitas guru dalam hal ini adalah pencapaian hasil yang baik dan tepat melalui kegairahan kerja. Dengan pemberian tunjangan ini maka para guru mendapatkan tambahan untuk memenuhi kebutuhan hidupnya, sedangkan bagi pemerintah akan memperoleh keuntungan berupa peningkatan produktifitas kerja.

Dalam undang-undang No 14 tahun 2005 tentang guru dan dosen tunjangan profesi atau kita biasa menyebut dengan tunjangan sertifikasi. Tunjangan profesi atau tunjangan sertifikasi adalah tunjangan yang diberikan kepada guru yang memiliki sertifikat pendidik sebagai penghargaan atas profesionalitasnya.

Berdasarkan beberapa pengertian di atas, dapat disimpulkan bahwa tunjangan merupakan suatu sarana untuk memberikan daya perangsang kepada guru dalam tugas yang diberikan kepadanya. Jadi pada pengertian ini tunjangan merupakan suatu cara atau sarana untuk menggerakkan tenaga kerja agar melakukan tugasnya sehingga apa yang dituju oleh instnasi atau organisasi dapat diraih dengan baik. 


\section{Kerangka Konseptual}

Kinerja sebagai hasil kerja yang dicapai dalam melaksanakan tugas-tugas yang dibebankan kepada guru yang didasarkan atas kecakapan, pengalaman dan kesungguhan serta waktu. Mangkunegara (2009) menyatakan bahwa "Kinerja adalah hasil kerja secara kualitas dan kuantitas yang dicapai oleh seorang guru dalam melaksanakan tugasnya sesuai dengan tanggung jawab yang diberikan kepadanya".

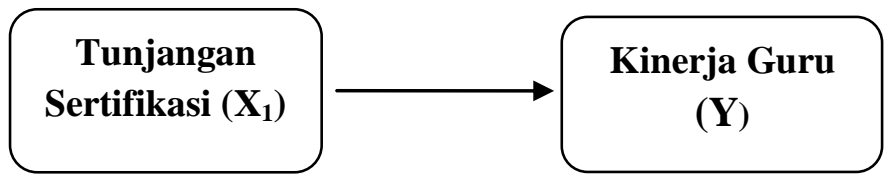

Gambar 1 Kerangka Konseptual

\section{Hipotesis Penelitian}

$\mathrm{H}_{1}$ :Tunjangan sertifikasi berpengaruh positif dan signifikan terhadap kinerja guru.

$\mathrm{H}_{0}$ :Tunjangan sertifikasi tidak berpengaruh positif dan signifikan terhadap kinerja guru.

\section{METODE PENELITIAN}

\section{Jenis dan Sifat Penelitian}

Jenis penelitian ini dengan menggunakan deskriptif kuantitatif yaitu penelitian yang mengukur kekuatan hubungan antara dua variabel atau lebih. Pendekatan yang digunakan dalam penelitian ini adalah pendekatan survey yaitu kegiatan mengumpulkan data sebanyak-banyaknya mengenai faktafakta yang merupakan pendukung terhadap penelitian dengan maksud untuk mengetahui status, gejala menemukan kesamaan status dengan cara membandingkan dengan standar yang sudah dipilih atau ditentukan (Arikunto, 2011)

Sifat dari penelitian ini adalah penelitian yang bersifat menjelaskan (deskriptif explanatory) yaitu penelitian yang bertujuan untuk memaparkan dan menjelaskan sifat suatu keadaan yang berlangsung pada saat penelitian dilakukan dan memeriksa penyebab dari gejala-gejala tersebut. kedudukan variabel-variabel yang diteliti serta hubungan antara variabel yang lain (Sugiyono, 2010).

\section{Populasi dan Sampel}

Menurut Sugiyono, (2010) "Populasi adalah sekelompok atau kumpulan individu-individu yang menjadi obyek penelitian yang memiliki standar dan ciri-ciri yang telah ditetapkan". Populasi dalam penelitian ini adalah seluruh guru Pegawai Negeri Sipil (PNS) pada seluruh SMP Negeri sekecamatan Meureubo Kabupaten Aceh Barat yang telah menerima tunjangan sertifikasi yaitu sebanyak 39 orang.

Menurut Arikunto (2011), sampel adalah sebagian atau wakil populasi yang diteliti, dan apabila subyek kurang dari 100 lebih baik diambil semua. Dalam penelitian ini digunakan sampling jenuh karena berdasarkan data populasi sebanyak 39 orang, maka seluruh populasi dijadikan sampel. 
Tabel 3

Distribusi Guru telah menerima tunjangan sertifikasi SMP Negeri se Kecamatan Meureubo Kabupaten Aceh Barat

\begin{tabular}{|c|c|c|c|}
\hline No & $\begin{array}{c}\text { Nama } \\
\text { Sekolah }\end{array}$ & $\begin{array}{c}\text { Jumlah } \\
\text { Populasi } \\
\text { (Orang) }\end{array}$ & $\begin{array}{c}\text { Sumlah } \\
\text { Sampel } \\
\text { (Orang) }\end{array}$ \\
\hline 1 & $\begin{array}{c}\text { SMP Negeri 1 } \\
\text { Meureubo }\end{array}$ & 4 & 4 \\
\hline 2 & $\begin{array}{c}\text { SMP Negeri 2 } \\
\text { Meureubo }\end{array}$ & 17 & 17 \\
\hline 3 & $\begin{array}{c}\text { SMP Negeri 3 } \\
\text { Meureubo }\end{array}$ & 4 & 4 \\
\hline 4 & $\begin{array}{c}\text { SMP Negeri 4 } \\
\text { Meureubo }\end{array}$ & 4 & 4 \\
\hline 5 & $\begin{array}{c}\text { SMP Negeri 5 } \\
\text { Meureubo }\end{array}$ & 4 & 4 \\
\hline 6 & $\begin{array}{c}\text { SMP Negeri 6 } \\
\text { Meureubo }\end{array}$ & 6 & 6 \\
\hline & Total & 39 & 39 \\
\hline
\end{tabular}

Sumber: Dinas Pendidikan Kabupaten Aceh Barat, Tahun 2015.

\section{Metode Pengumpulan Data}

Untuk memperoleh data yang lengkap dan teliti, peneliti menggunakan teknik pengumpulan data melaui wawancara (Interview), penyebaran daftar pertanyaan (Questionaire) dan Studi dokumentasi dari catatan-catatan yang ada sehubungan dengan data yang diperoleh dari Dinas Pendidikan Kabupaten Aceh Barat

\section{Jenis Dan Sumber Data}

Jenis data yang dikumpulkan untuk mendukung variabel yang diteliti adalah data primer data sekunder.

\section{Uji Validitas}

Menurut Idrus (2009) Validitas adalah apabila instrument tersebut betul-betul mengukur apa yang seharusnya diukur. Butir-butir pertanyaan dicobakan pada 30 orang responden yang diambil dari luar sampel dan dilakukan di guru PNS SMP Negeri sekecamatan Meureubo Kabupaten Aceh Barat. Pengujian validitas dilakukan dengan menggunakan program SPSS dengan kriteria sebagai berikut: Jika $r$ hitung $\geq r$ tabel, maka pertanyaan dinyatakan valid, Jika $r$ hitung $<r$ tabel, maka pertanyaan dinyatakan tidak valid. Hail pengujian instrument variabel tunjangan sertifikasi guru (X1) menunjukkan bahwa semua nilai Corrected Item-Total Correction lebih besar dari 0,361. Hal ini menunjukkan bahwa instrumen penelitian dikatakan valid dan selanjutnya dapat digunakan dalam penelitian ini. 


\section{Uji Realibilitas}

Menurut Idrus (2009), uji realibilitas adalah tingkat keajekan instrumen saat digunakan kapan dan siapa saja sehingga akan cenderung menghasilkan data yang sama atau hampir sama dengan data sebelumnya. Uji reliabilitas terhadap variabel penelitian ini dikatakan reliabel jika memberikan nilai Cronbach Alpha> 0,60 (Ghozali, 2009). Hasil pengujian reliabilitas instrumen variabel penelitian menunjukkan nilai Cronbach's Alpha lebih besar dari 0,6 yang berarti bahwa instrument variabel penelitian adalah reliable.

\section{Metode Analisis Data}

Metode analisis data yang digunakan dalam penelitian inimeliputi analisis deskriptif dan analsisi inferensial. Analisis inferensial menggunakan korelasi parsial dan regresi ganda.semua proses analisis menggunakan bantan program SPSS for windows.

\section{HASIL DAN PEMBAHASAN}

\section{Karakteristik Responden}

Karakteristik responden ini dalam penelitian ini berdasarkan beberapa kriteria :

a. Jenis Kelamin

Secara umum guru sertifikasi di Kecamatan Meureubo didominasi oleh perempuan. Hal ini dikarenakan banyak wanita yang menyukai profesi guru, profesi ini juga dianggap pekerjaan yang cocok untuk wanita karena guru pekerjaan yang tidak menghabis waktu seharian

b. Masa Kerja

masa kerja bahwa guru sertifikasi se Kecataman Meureubo Kabupaten Aceh Barat masa kerjanya relatif lama. Hal ini disebabkan oleh salah satu syarat agar diusulkan menjadi guru penerima tunjangan sertifikasi adalah yang telah memiliki masa kerja cukup lama sehingga banyak guru baru yang masih menunggu giliran untuk diberikan sertifikasi

c. Pendidikan

guru sertifikasi se Kecataman Meureubo Kabupaten Aceh Barat hampir seluruhnya berpendidikan Sarjana. Salah satu syarat untuk untuk menjadi guru dan di usulkan menerima tunjangan sertifikasi adalah minimal Memiliki kualifikasi akademik sarjana (S-1) atau diploma empat (DIV).

d. Usia

guru sertifikasi se Kecataman Meureubo Kabupaten Aceh Barat yang lebih dominan adalah berusia 45 sampai 49 tahun, hal ini menunjukkan bahwa sebagian besar guru sudah memiliki pengalaman mengajar dan sudah matang sehingga dalam menjalankan tugas-tugas mengajar sudah lebih teliti dan terampil.

\section{Hasil Penelitian}

Berdasarkan hasil analisis deskriftif, secara umum dapat diketahui secara keseluruhan memiliki kinerja yang baik, hal ini dapat terlihat berdasarkan dari total rata-rata skor sebesar 4.42 (nilai rata-rata skor 4.21-5.00 Kategori Sangat Setuju) artinya berada pada kategori sangat setuju, dimana tingkat kinerja guru di SMP Negeri sekecamatan Meuruebo Kabupaten Aceh Barat kategori tinggi. 
Berdasarkan hasil analisis regresi linier berganda ditemukan koefisien determinan $\left(R^{2}\right)=0,360$ yang berarti sekitar 36,0\% pengaruh tunjangan sertifikasi terhadap kinerja guru SMP Negeri sekecamatan Meureubo Kabupaten Aceh barat dan sisanya sebesar 64,0\% dipengaruhi oleh faktor lain yang tidak diteliti dalam penelitian ini.

Hasil uji F diperoleh $F_{\text {hitung }}=22,330$ (sig=0,000 < 0,05). Karena signifikansi lebih kecil dari 0,05 berarti pengaruh tersebut sangat signifikan. Dengan kata lain variabel tunjangan sertifikasi guru memberikan sumbangan positif yang sangat berarti terhadap kinerja guru SMP Negeri sekecamatan Meureubo Kabupaten Aceh Barat. Semakin besar tunjangan sertifikasi maka akan meningkatkan kinerja guru.

Berdasarkan perhitungan tersebut diatas dapat disimpulkan bahwa tunjangan sertifikasi berpengaruh positif dan signifikan terhadap kinerja guru SMP Negeri sekecamatan Meureubo kabupaten Aceh Barat. Besarnya sumbangan variable tunjangan sertifikasi terhadap kinerja guru adalah sebesar 36\%. Dengan demikian hipotesis penelitian yang menyatakan: "Tunjangan sertifikasi berpengaruh positif dan signifikan terhadap kinerja guru" dapat diterima.

Berdasarkan pada nilai koefisien beta (B) dalam persamaan regresi dapat diketahui bahwa besarnya pengaruh dari masing-masing aspek tunjangan sertifikasi terhadap kinerja guru

\section{Kesimpulan dan saran}

Berdasarkan hasil analisis data dan pembahasan hasil penelitian dapat diambil kesimpulan sebagai berikut :

1. Hasil pengujian menunjukkan bahwa tunjangan sertifikasi berpengaruh positif dan signifikan terhadap kinerja guru SMP Negeri se Kecamatan Meurebo Kabupaten Aceh Barat. Artinya, semakin besar tunjangan sertifikasi maka akan semakin meningkatkan kinerja guru, sebaliknya semakin sedikit tunjangan sertifikasi maka akan semakin menurunkan kinerja guru

2. Secara umum dapat diketahui secara keseluruhan memiliki kinerja yang baik, hal ini dapat terlihat berdasarkan dari total rata-rata skor sebesar 4.42 artinya berada pada kategori sangat setuju, dimana tingkat kinerja guru di SMP Negeri sekecamatan Meuruebo Kabupaten Aceh Barat kategori tinggi

3. Dengan adanya pemberian tunjangan sertifikasi diharapkan dapat meningkatknya kinerja guru, menurunkan tingkat absensi, jam masuk kantor sesuai dengan yang sudah ditentukan, sehingga hal tersebut dapat mendorong guru bekerja dengan lebih giat, semangat dan penuh rasa tanggung jawab terhadap pekerjaannya. tunjangan sertifikasi sebagai sarana motivasi yang mendorong para guru untuk bekerja dengan kemampuan yang optimal, yang dimaksudkan sebagai pendapatan ekstra di luar gaji atau upah yang telah ditentukan. Pemberian tunjangan sertifikasi dimaksudkan agar dapat memenuhi kebutuhan para guru dan keluarga mereka.

Berdasarkan kseimpulan diatas maka dapat diajukan saran-saran sebagai berikut :

1. Ditinjau dari tunjangan sertifikasiguru SMP Negeri se Kecamatan Meureubo Kabupaten Aceh Barat disarankan agar tunjangan sertifikasi diberikan dengan memperhatikan kepuasan guru..

2. Dinas Pendidikan Aceh Barat perlu mempertimbangkan jumlah jam mengajar yang tersedia di setiap sekolah dalam menempatkan stiap guru sehingga guru tidak perlu mencari jam menjajar diluar sekolah tempat bertugas, karena saat ini banyak guru-guru yang telah menerima tunjangan tetapi tidak mencukupi jam mengajar disekolah tempat bertugas, sehingga mereka harus mencari jam keluar sekolah bertugas. Hal ini dirasa cukup memberatkan guru-guru, sebab jika jam 
mengajar tersebut tidak terpenuhi maka uang sertifikasi tidak dapat dicairkan. Maka di sarankan kepada Dinas Pendidikan Aceh Barat agar menyesuaikan penempatan guru disetiap sekolah sesuai dengan jam mengajar yang tersedia, sehingga setiap guru mendapat jam mengajar sesuai dengan mata pelajaran yang diampu tanpa harus mengajar disekolah lain. 


\section{DAFTAR PUSTAKA}

Arikunto, Suharsimi. 2011. Prosedur Penelitian Praktek. Jakarta: Rineka Cipta.

Ghozali, Imam. 2009. Aplikasi Analisis Multivariate dengan Program SPSS. Semarang : Universitas Diponegoro.

Hasibuan, Malayu S.P. 2005. Manajemen Sumber Daya Manusia, Edisi Revisi Cetakan ketujuh. Penerbit : Bumi Aksara Jakarta.

Idrus, Muhammad. 2009. Metode Penelitian Ilmu Sosial, Edisi Kedua, Erlangga, Jakarta.

Ilyas, Yaslis. 2001. Kinerja: Teori Peniaian dan Penelitian. Jakarta: Pusat Kajian Ekonomi Kesmas Universitas Indonesia.

Mangkunegara, A.A. Prabu. 2009. Manajemen Sumber Daya Manusia Perusahaan. Bandung: PT Remaja Rosdakarya.

Mulyasa, E. 2008. Kurikulum Tingkat Satuan Pendidikan. Bandung: PT. Remaja Rosdakarya Offsed.

Nawawi, Hadari. 2008. Manajemen Sumber Daya Manusia untuk Bisnis yang Kompetitif. Yogyakarta: Gadjah Mada University Press.

Sugiyono. 2011. Metode Penelitian Kuantitatif Kualitatif dan $R \& D$. Alfabeta Bandung.

UNDANG-UNDANG REPUBLIK INDONESIA Nomor 14 tahun 2005 tentang guru dan dosen.

Wibowo. 2012. Manajemen Kinerja Edisi Ketiga, Cetakan Keenam, PT. Raja Grafindo Persada, Jakarta. 